\title{
Pengaruh berbagi informasi terhadap kualitas produk yang dimediasi oleh keselarasan kualitas: Studi pada Kedai Kopi di Kabupaten Sleman, D. I. Yogyakarta
}

\author{
Fatahillah Akbar Kalam ${ }^{1}$ \\ Titik Kusmantini ${ }^{2}$ \\ Sri Isworo Ediningsih ${ }^{3}$ \\ ${ }^{1}$ Mahasiswa Fakultas Ekonomi dan Bisnis, Universitas Pembangunan Nasional Yogyakarta \\ ${ }^{2}$ Pengajar Fakultas Ekonomi dan Bisnis, Universitas Pembangunan Nasional Yogyakarta \\ Email korespondensi: titik.kusmantini@upnyk.ac.id
}

\begin{abstract}
The purposes of this research are to determine the effect of Information Sharing and Product Quality with the mediation of Conformance Quality. The type of this research is observatory research, with a quantitative method approach. The research took place at Sleman, Yogyakarta. The size of the samples 65 coffee shops. The sampling technique uses convenience sampling. The data analysis techniques used in this research are path analysis and linear regression. The results of this research show that there is a significant effect of information sharing and conformance quality on product quality. There is a significant effect of information sharing on conformance quality. There is a significant effect of conformance quality as the mediation of information sharing and product quality. The result of this research demonstrated there is an effect on each other variables.
\end{abstract}

Keywords: Information sharing; product quality; conformance quality

\section{Pendahuluan}

Kopi merupakan salah satu bentuk bisnis yang sedang berkembang di Indonesia, karena konsumsi kopi di Indonesia terbilang cukup besar, berdasarkan Pusat Data dan Sistem Informasi Pertanian Kementerian Pertanian konsumsi kopi nasional pada 2016 mencapai sekitar 250 ribu ton dan tumbuh 10,54\% menjadi 276 ribu ton. Konsumsi kopi Indonesia sepanjang periode 2016-2021 diprediksi tumbuh rata-rata 8,22\%/tahun. Pada 2021, pasokan kopi diprediksi mencapai 795 ribu ton dengan konsumsi 370 ribu ton, sehingga terjadi surplus 425 ribu ton. Gambaran ini menyimpulkan adanya fenomena baru, yaitu memunculnya atau tumbuhnya usaha kopi (kedai kopi) sebagai peluang bisnis.

Fenomena kedai kopi yang sedang terjadi tentu disebabkan oleh beberapa faktor. Beberapa alasan kenapa bisnis kedai kopi mulai diminati antara lain, karena kedai kopi diminati oleh hampir semua kalangan, menjadikan kedai kopi memiliki pasar yang cukup luas. Peluang pertumbuhan omzet dari kedai kopi ini juga dipengaruhi oleh faktor gaya hidup, seperti digunakan sebagai tempat pertemuan atau sekadar untuk bersantai. Dalam hal ini diperlukan upaya pengelolaan dari kedai kopi tersebut. Pengelolaan di sini yang dimaksud seperti memberikan atau menambah fasilitas yang berguna untuk meningkatkan keunggulan bersaing, seperti fasilitas pendingin ruangan, ketersediaan wi-fi atau hotspot, toilet, dan jika memungkinkan memberikan fasilitas area khusus untuk meeting. Fasilitasfasilitas tambahan seperti itu dapat meningkatkan nilai lebih dari kedai tersebut. Selain fasilitas, juga perhatikan hal seperti perbanyak menu, penyediaan makanan ringan, serta jam buka kedai. Semua itu dilakukan untuk menciptakan keunggulan bersaing atau keunikan tersendiri dari sebuah kedai kopi. Untuk menciptakan keunggulan bersaing, salah satu yang 
juga diperlukan adalah pengelolaan yang tepat, di sini pengelolaan bahan baku yang dijadikan fokusnya. Pengelolaan bahan baku biji kopi sebagai bahan baku utama membutuhkan dukungan pemasok, agar pemasok mengirim bahan baku biji kopi sesuai kriteria biji kopi yang ditentukan oleh kedai kopi. Dengan pemilihan pemasok yang tepat dan kerja sama yang sehat adalah faktor utama. Karena pemasok berperan penting dalam menentukan mutu produk, biaya, pengembangan produk, dan akses pembiayaan bagi kedai kopi. Mutu produk dan layanan, sebagai penentu kepuasan pelanggan, salah satunya bergantung pada kualitas pemasoknya. Pasokan yang berkualitas akan memudahkan kedai kopi menghasilkan produk dan layanan yang berkualitas pula. Maka dari itu, dibutuhkan hubungan kerja sama yang baik dengan pemasok.

Kerja sama dengan pemasok kopi yang dibangun di sini perlu diperhatikan karena merupakan penentu kualitas produk dari kedai kopi. Hubungan kerja sama dalam hal pasokan kopi di sini diperlukannya saling bertukar informasi dari kedua pihak karena untuk menjaga kualitas produk kedai kopi dibutuhkan konsistensi dari pemasok kopi dalam kualitas biji kopi dari pemasok, serta jadwal pengirimannya. Pemilihan biji kopi dari pemasok juga tidak sembarangan, berikut hasil wawancara dengan Bapak Safrian, (Barista kedai kopi Space Coffee Roastery, 2019), spesifikasi dalam memilih kualitas biji kopi, seperti ukuran biji yang seragam dan sewarna, besar kecilnya tidak berpengaruh asalkan seragam. Setelah itu dilihat dari warnanya, dapat dilihat dari kerutan dan warnanya. Yang terakhir adalah mengecek kerusakan pada biji, seperti biji yang pecah atau berlubang, berwarna hitam atau coklat, dan bahkan mungkin terbelah dua. Kerja sama antara pemasok dan kedai kopi dalam rantai pasok ini didefinisikan sebagai hubungan jangka panjang di pihak yang saling berinteraksi. Biasanya bekerja sama, berbagi informasi, berbagi perencanaan bisnis, dan bahkan memodifikasi praktik bisnis mereka untuk meningkatkan kinerja bersama (Whipple et al., 2010).

Berkaitan dengan kedai kopi dan pemasok dalam rantai pasokan, yang diperlukan untuk kelancaran manajemen rantai pasok tersebut adalah adanya berbagi informasi antara berbagai pelaku dalam rantai pasokan. Berbagi informasi dalam rantai pasokan dilakukan untuk meningkatkan kelancaran rantai pasokan, karena menghubungkan antara arus informasi, keuangan, bahan baku, serta pemasokan, pengecer, distributor, dan yang terakhir konsumen. Inti dari berbagi informasi adalah untuk mengoptimasi beban biaya yang digunakan. Berbagi informasi artinya mendistribusikan informasi yang berguna untuk sistem, orang dan juga unit organisasi. Berbagi informasi juga bisa dikatakan sebagai "berbagi ilmu" dan "integrasi informasi". Dan juga nantinya pengaruh berbagi informasi ini akan berpengaruh pada kualitas produk. Dalam hal ini, rekan dari rantai pasokan ini perlu untuk meningkatkan manfaat kompetitif dari berbagi informasi. Dengan berbagi informasi yang lancar maka akan berpengaruh pada konsumen yang mendapatkan kualitas produk lebih tinggi dengan beban biaya yang berkurang serta periode waktu yang lebih pendek.

Integrasi antara rantai pasokan berpacu pada 3 hal yaitu manfaat, aktivitas dan komponen/pemilihannya. Dari hal tersebut bisa dibagi lagi seperti manfaat untuk meningkatkan efisiensi, nilai dan kepuasan konsumen, yang mana semua ini terdapat pada 
hubungan antara manajemen rantai pasokan dan kualitas produk. Proses rantai pasokan inilah yang nantinya membentuk kualitas produk keluaran dalam bentuk secangkir kopi.

Mengenai penelitian langsung dari berbagi informasi terhadap kualitas produk, sudah pernah dibahas oleh beberapa peneliti seperti Lotfi., et al (2013) yang membahas kedua variabel, tetapi hanya meneliti tentang integrasi rantai pasokan terhadap kualitas produk secara garis besar. Di sini yang akan dibahas lebih spesifik ke salah satu dimensi dari integrasi rantai pasokan, yaitu berbagi informasi, terhadap kualitas produk, tetapi dimediasi oleh keselarasan kualitas.

Keselarasan kualitas di sini dapat dikatakan sebagai upaya untuk menyelaraskan kualitas produk kopi, tentu saja lewat menyelaraskan bahan baku utama kopi yaitu biji kopinya. Biji kopi yang didapat dari pemasok tidak selalu berjalan dengan baik pada saat proses rantai pasok tersebut, bisa dikatakan bahan baku biji kopi tersebut dapat berubah kualitas atau diganti dengan jenis biji kopinya. Maka dari itu di sini pentingnya berbagi informasi dalam menjaga kualitas produk melalui penyelarasan bahan baku utama dari biji kopi tersebut. Biji kopi yang berkualitas dapat dilihat dari bentuknya yang seragam, warnanya tidak pucat/ keputihan, serta tidak terdapat lubang atau retak bahkan sampai pecah, tingkat kekeringan yang pas dan juga tidak beraroma apek.

Kualitas produk menurut Juran (2007) dan Montgomery (2007), "kualitas" berarti "kemampuan untuk digunakan" yang berarti kualitas digunakan sesuai kemampuan dan sesuai dengan kebutuhan. Kualitas produk juga berarti memenuhi kebutuhan antara kebutuhan konsumen dan juga kepuasan konsumen. Dari kualitas produk ini terdapat penyelarasan kualitas, yang mencakup desain produk, proses desain, struktur produk, dan fungsi dari produk. Penyelarasan kualitas menurut Clark dan Fujimoto (1991) berpacu pada seberapa produk disampaikan kepada konsumen dan penyesuaian pada desain produk/spesifikasi, termasuk uji ketahanan, kecacatan, finishing, dan daya tahan.

Dengan begitu, dibutuhkanlah adanya integrasi rantai pasokan antara pemasok dan kedai kopi tersebut untuk menjaga kualitas produk, dengan salah satu caranya adalah menjaga kualitas informasi dalam berbagi informasi antar pemasok, serta dengan menyelaraskan kualitas untuk menjaga kualitas dari produk keluaran.

\section{Tinjauan Pustaka}

\subsection{Integrasi Rantai Pasokan}

Integrasi rantai pasokan dapat didefinisikan sebagai kolaborasi antara pihak dari manufaktur dan rekan rantai pasokannya dengan tepat untuk mengadakan proses dari internal maupun dari pihak eksternal (Flynn et al., 2010). Integrasi internal di sini diartikan sebagai integrasi dari bahan baku maupun distribusi dari tiap departemen. Sedangkan pihak eksternal dari sini yang dimaksud adalah dari konsumen dan integrasi dari pihak pemasok. Integrasi internal di sini dibutuhkan untuk mengintegrasikan fungsi dari manajemen bahan baku kepada pihak produksi, dan dibutuhkan integrasi lintas fungsi dalam kendali perusahaan untuk tercapainya kepuasan pelanggan. 


\subsection{Berbagi Informasi}

Berbagi informasi adalah kunci dari bahan utama untuk segala macam sistem rantai pasokan. Dikatakan begitu karena berbagi informasi yang selalu diperbarui menjadikan rantai pasokan berjalan lancar. Dengan informasi yang tersedia dan membagikannya dengan pihak kerja sama yang lain dapat meningkatkan tingkat aliran informasi yang terjadi dalam rantai pasokan, meningkatkan efisiensi dan efektivitas dalam rantai pasokan, dan respon terhadap konsumen menjadi lebih cepat. Maka dari itu, berbagi informasi membawa organisasi meningkatkan tingkat persaingan jangka panjangnya (Chapman dan Carter, 1997).

\subsection{Keselarasan Kualitas (Conformance Quality)}

Keselarasan (Conformance Quality) menurut Garvin (dalam Boyd \& Larreche, 2000) adalah cara bagaimana karakteristik operasi sebuah produk memenuhi spesifikasi tertentu, sedangkan menurut Kotler dan Armstrong (2007) adalah konsistensi menunjukkan seberapa jauh suatu produk dapat menyamai standar atau spesifikasi tertentu. Kualitas dari keselarasan ini juga bisa dikatakan adalah salah satu definisi dari kualitas (Garvin, 1988; Reeves \& Bednar, 1994).

\subsection{Kualitas Produk}

Menurut Kotler (2005), "Kualitas produk adalah keseluruhan ciri serta dari suatu produk atau pelayanan pada kemampuan untuk memuaskan kebutuhan yang dinyatakan/ tersirat". Sedangkan menurut Lupiyoadi (2001) menyatakan bahwa "Konsumen akan merasa puas apabila hasil evaluasi mereka menunjukkan bahwa produk yang mereka gunakan berkualitas".

\subsection{Telaah Penelitian Sebelumnya}

Dalam penelitian ini penulis memaparkan penilitian terdahulu yang relevan dengan permasalahan yang akan diteliti tentang pengaruh manajemen rantai pasokan khususnya dimensi berbagi informasi terhadap kualitas produk dengan mediasi keselarasan kualitas pada kedai kopi di Sleman Yogyakarta. Konsep yang dipakai oleh penulis adalah penilitian Lotfi et al., (2013a) yang meneliti tentang hubungan antara integrasi rantai pasokan dengan kualitas produk. Serta Lotfi et al (2013c) memaparkan analisis pengaruh integrasi rantai pasokan dengan indikator integrasi pelanggan, integrasi internal, dan integrasi pemasok berpengaruh terhadap kualitas produk dengan indikator kualitas desain dan keselarasan kualitas. Jurnal ini merupakan jurnal lanjutan dari Lotfi et al., (2013a).

Hasilnya menunjukkan bahwa integrasi rantai pasokan memengaruhi produk kualitas, baik itu dari dimensi integrasi rantai pasokan dan dari dimensi kualitas produk. Yang mana hal ini dikatakan dapat meningkatkan kemampuan kompetitif di perusahaan. Lotfi et al (2013b) memaparkan tentang berbagi informasi adalah faktor yang cukup penting dalam manajemen rantai pasokan. Dikatakan bahwa berbagi informasi dapat berperan dalam manajemen rantai pasokan dengan hasil memberi manfaat seperti berkurangnya persediaan yang efisien, beban yang berkurang, meningkatkan visibilitas, 
meningkatkan pemanfaatan sumber daya, meningkatkan produktivitas, efisiensi pengorganisasian, meningkatkan pelayanan, respon cepat, efisiensi siklus waktu, kemudahan dalam pelacakan, jaringan yang berkembang, dan juga siklus utilitas yang dimaksimalkan.

Berbagi informasi memungkinkan semua anggota yang terkait dalam manajemen rantai pasokan untuk mendapatkan, menjaga, dan menyampaikan informasi untuk memastikan pengambilan keputusan menjadi efektif dan merupakan faktor yang mampu mempererat elemen-elemen manajemen rantai pasokan secara keseluruhan, oleh karena itu masalah yang dihadapi dapat dikurangi dengan adanya berbagi informasi. Lotfi et al (2013c) menyimpulkan bahwa integrasi rantai pasokan, baik itu integrasi internal, integrasi dengan pemasok atau non konsumen memiliki pengaruh langsung dan positif terhadap dimensi keselarasan kualitas dan kualitas desain, dan berpengaruh tidak langsung terhadap kualitas produk melalui keselarasan kualitas dan kualitas desain. Dalam penelitian ini menguji pengaruh langsung berbagi informasi terhadap kualitas produk, dan pengaruh tidak langsung berbagi informasi terhadap kualitas produk melalu keselarasan kualitas.

Selain itu, Lotfi et al (2013b) juga menjelaskan dengan memberikan informasi yang penting dan berguna bagi sistem, orang-orang, atau unit organisasi akan memiliki dampak yang positif akan kualitas produknya, karena di sini para rekan dari rantai pasokan akan otomatis meningkatkan keunggulan bersaingnya. Keunggulan bersaing juga akan ikut serta dalam meningkatkan kualitas produknya.

\section{$H_{1}$ : Berbagi informasi berpengaruh langsung dan positif terhadap kualitas produk}

Keselarasan kualitas di sini mencerminkan keselarasan spesifikasi dalam operasi, atau aspek kualitas yang berorientasi secara internal. Kepatuhan yang tinggi pada spesifikasi berasal dari tingkat konsistensi yang tinggi dan variasi yang rendah pada proses internal. Keselarasan kualitas yang baik tercapai saat semua hal yang dilakukan dengan sesuai, ketika efisiensinya tinggi (Merirovich, 2006).

Lotfi et al (2013c) mengatakan bahwa integrasi rantai pasok mempengaruhi kualitas produk secara tidak langsung melalui keselarasan kualitas terlebih dahulu, karena berbagi informasi merupakan bagian dari integrasi rantai pasok. Maka hal ini menyatakan berbagi informasi ikut andil dalam memengaruhi keselarasan kualitasnya.

\section{$\mathrm{H}_{2}$ : $\quad$ Berbagi informasi berpengaruh langsung dan positif terhadap keselarasan kualitas}

Fujimoto (1999) dalam Lotfi et al (2013) mendefinisikan bahwa sebenarnya kualitas produk merupakan penyesuaian dari proses informasi bahan baku produktif dari rantai pasokan yang berkaitan dengan kebutuhan konsumen, konsep produk, rencana produk, desain produk, proses desain, struktur produk dan fungsi dari produk. Maka dibedakan menjadi lebih sederhana yaitu kualitas desain dan keselarasan kualitas. Namun dalam penelitian ini disederhanakan dengan tidak menggunakan kualitas desain dan hanya menggunakan keselarasan kualitasnya saja. 
Konsep kinerja kualitas menurut Lotfi., et al (2013c) dicapai karena pengaruh berbagi informasi dengan kualitasnya, dan tidak langsung berbagi informasi terhadap kualitas produk melalui keselarasan kualitas. Pengaruh dari keselarasan kualitas dapat dikatakan bersinggungan secara langsung dengan kualitas produk, namun dalam penelitian ini tidak diikut sertakan kualitas desain karena menyesuaikan dengan variabel kualitas produk yang tidak membutuhkan proses produksi yang kompleks jadi dirasa keselarasan kualitas mencukupi sebagai mediasi, dan menghilangkan kualitas desain. Seperti yang dipaparkan Lotfi et al (2013c) membuktikan kualitas desain dan keselarasan kualitas, berpengaruh positif terhadap kualitas produk.

\section{$H_{3}$ : $\quad$ Keselarasan kualitas berpengaruh langsung dan positif terhadap kualitas produk}

Lotfi et al (2013c) menyatakan integrasi rantai pasokan tidak berpengaruh langsung terhadap kualitas produk, tetapi menggunakan mediasi kualitas desain dan keselarasan kualitas, yang nantinya baru berpengaruh langsung terhadap kualitas produk. Dan dalam jurnal tersebut menunjukkan hasil yang positif. Berbagi informasi di sini merupakan salah satu faktor dari integrasi rantai pasokan tersebut.

$H_{4}$ : Berbagi informasi berpengaruh secara tidak langsung terhadap kualitas produk dengan dimediasi keselarasan kualitas

Berdasarkan hipotesis maka kerangka penelitian untuk menelusuri hubungan berbagai pengaruh variabel diilustrasikan dalam gambar sebagai berikut:

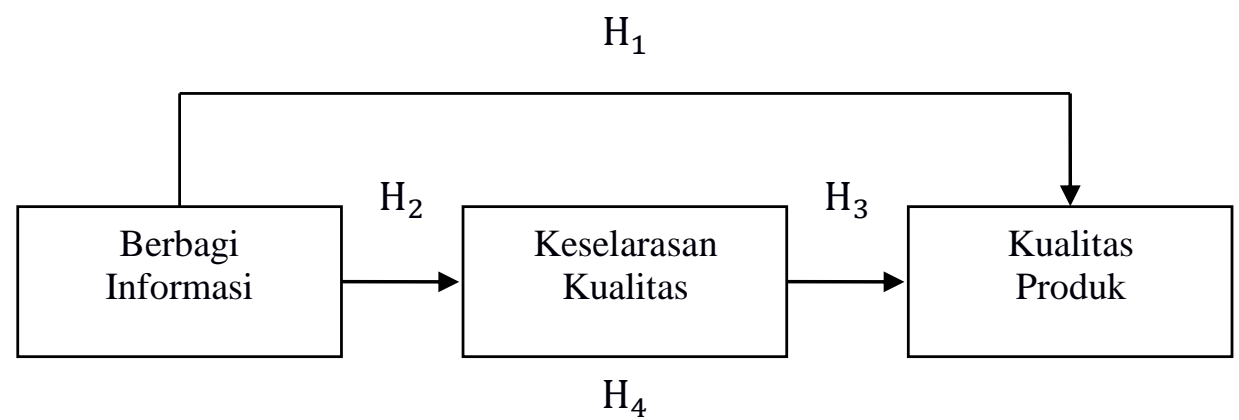

Gambar 1. Kerangka penelitian

\section{Metode penelitian}

Penelitian ini merupakan penelitian deskriptif kuantitatif. Penelitian deskriptif adalah suatu metode penelitian yang digunakan untuk menggambarkan fenomena-fenomena yang ada dan berlangsung pada saat ini maupun pada saat yang lampau, dalam metode deskriptif dapat digunakan pendekatan kuantitatif berupa pengumpulan dan pengukuran data yang berbentuk angka (Sugiyono, 2010). Sedangkan rancangan penelitian ditinjau dari sifat datanya merupakan penelitian observasi, yaitu metode dengan mengamati dan mendengar dalam rangka memahami, mencari jawaban, mencari bukti terhadap fenomena sosial selama beberapa waktu tanpa memengaruhi fenomena yang diobservasi (Sugiyono, 2010). 
Populasi adalah wilayah generalisasi yang terdiri atas obyek atau subyek yang mempunyai kualitas dan karakteristik tertentu yang ditetapkan oleh peneliti untuk dipelajari dan kemudian ditarik kesimpulannya (Sugiyono, 2010). Populasi dari penelitian ini adalah kedai kopi yang berada di wilayah Sleman, Yogyakarta.

Sampel sebagai sebagian dari jumlah dan karakteristik yang diambil dari populasi penelitian yang sudah ditentukan. Keterbatasan wilayah membuat peneliti memutuskan untuk mengambil beberapa sampel dari populasi penelitian ini dengan mengacu pada kriteria jumlah sampel yang bisa digunakan. Ukuran sampel yang layak menurut Sugiyono (2010) adalah antara 30 sampai dengan 500. Maka dalam penelitian ini akan mengambil sampel sebesar 65 sampel.

Karena populasi dalam penelitian ini bersifat acak, maka digunakan teknik non probability sampling karena peluang elemen untuk ditentukan sebagai sampel tidak diketahui, dan juga karena masalah generalisasi tidak diperlukan, maka teknik ini yang tepat untuk digunakan. Maka dalam penelitian ini digunakanlah teknik non probability sampling yang di dalamnya dilakukan dengan teknik convienience sampling menurut Sekaran (2006) adalah sebagai kumpulan informasi dari anggota-anggota populasi yang mudah diperoleh sampling. Definisi convienience sampling menurut Sekaran (2006) adalah sebagai kumpulan informasi dari anggota-anggota populasi yang mudah diperoleh dan mampu menyediakan informasi tersebut. Dengan demikian kedai kopi mana saja yang dapat memberikan informasi dan berada dalam cakupan wilayah yang ditentukan oleh peneliti dapat digunakan sebagai sampel, bila dilihat orang yang memberikan informasi-informasi tersebut cocok sebagai sumber data (Sekaran, 2006).

Jenis data yang digunakan adalah data primer. Menurut Sugiyono (2010), sumber data primer adalah sumber data yang langsung memberikan data kepada pengumpul data. Data primer yang ada dalam penelitian ini merupakan data persepsian pemilik kedai kopi maupun pengelola kedai kopi tentang variabel berbagi informasi, keselarasan kualitas, dan kualitas produk.

Teknik mengumpulkan data dalam penelitian ini menggunakan teknik wawancara dan penyebaran kuisioner. Menurut Sugiyono (2010), wawancara adalah pertemuan dua orang untuk bertukar informasi dan ide melalui tanya jawab, sehingga dapat dikontruksikan makna dalam suatu topik tertentu. Dalam penelitian ini, wawancara dilakukan dengan pemilik kedai kopi atau dengan barista untuk mendapatkan beberapa data dan informasi tambahan.

Selain wawancara, dilakukan juga penyebaran kuisioner, kuisioner adalah teknik pengumpulan data yang dilakukan dengan cara memberi seperangkat pertanyaan atau pertanyaan tertulis kepada responden untuk dijawabnya (Sugiyono, 2010). Mengumpulkan data dengan mengirim pertanyaan untuk diisi sendiri oleh responden, dilakkan dengan menyebar form kuisioner secara langsung didistribusikan ke target responden penelitian. 
Tabel 1: Operasionalisasi Variabel Penelitian

\begin{tabular}{|c|c|c|c|}
\hline Variabel & Definisi Operasional & Indikator & Sumber \\
\hline $\begin{array}{l}\text { Berbagi } \\
\text { Informasi }\end{array}$ & $\begin{array}{l}\text { Berbagi informasi adalah aliran } \\
\text { komunikasi secara terus menerus antara } \\
\text { mitra kerja baik formal maupun informal } \\
\text { dan berkontribusi untuk suatu } \\
\text { perencanan serta pengawasan yang lebih } \\
\text { baik dalam sebuah rangkaian (Miguel } \\
\text { dan Brito, 2011). }\end{array}$ & $\begin{array}{l}\text { 1. Bertukar informasi } \\
\text { 2. Penyesuaian informasi } \\
\text { 3. Detail perencanaan } \\
\text { 4. Kelengkapan informasi } \\
\text { 5. Pelibatan pemasok }\end{array}$ & $\begin{array}{l}\text { Li et al., } \\
\text { (2006) }\end{array}$ \\
\hline $\begin{array}{l}\text { Keselarasan } \\
\text { Kualitas }\end{array}$ & $\begin{array}{l}\text { Keselarasan menurut Garvin (dalam } \\
\text { Boyd \& Larreche, 2000) adalah cara } \\
\text { bagaimana karakteristik operasi sebuah } \\
\text { produk memenuhi spesifikasi tertentu. }\end{array}$ & $\begin{array}{l}\text { 1. Hal ukuran } \\
\text { 2. Hal konsistensi warna } \\
\text { 3. Hal aroma } \\
\text { 4. Minimalisasi cacat } \\
\text { 5. Hal kekeringan }\end{array}$ & $\begin{array}{l}\text { Boyd \& } \\
\text { Larreche, } \\
\text { (2000); Kotler } \\
\text { \& Armstrong } \\
\text { (2005); } \\
\text { Meirovich } \\
\text { (2006) }\end{array}$ \\
\hline Kualitas Produk & $\begin{array}{l}\text { Kualitas produk adalah keseluruhan ciri } \\
\text { serta dari suatu produk atau pelayanan } \\
\text { pada kemampuan untuk memuaskan } \\
\text { kebutuhan yang dinyatakan/ tersirat } \\
\text { (Kotler, 2007). }\end{array}$ & $\begin{array}{l}\text { 1. Porsi yang tepat } \\
\text { 2. Standar resep } \\
\text { 3. Penampilan } \\
\text { 4. Tingkat kebersihan } \\
\text { 5. Ketepatan waktu }\end{array}$ & Bartono (2005) \\
\hline
\end{tabular}

\section{Hasil dan pembahasan}

Tabel 2. Ringkasan Hasil Analisis Regresi Tahap I

\begin{tabular}{lrll}
\hline \multicolumn{1}{r}{ Variabel Independen } & B & t & Sig. \\
\hline Konstanta & 5,299 & 2,164 & $0,034^{*}$ \\
Berbagi Informasi (BI) & 0,745 & 6,784 & $0,000^{* *}$ \\
\hline
\end{tabular}

Variabel dependen: Keselarasan Kualitas

Adjusted R Square $=0,413$

$\frac{\mathrm{F}=46,028, \text { Sig. } \mathrm{F}=0,000 * *}{* * \mathrm{Sig}<1 \%, * \mathrm{Sig}<5 \%}$

Berdasarkan tabel 2 dapat diketahui persamaan regresi yang diperoleh adalah $\mathrm{Z}=$ $5.299+0,745$ X. Dari hasil tersebut menunjukkan bahwa nilai koefisien berbagi informasi terhadap keselarasan kualitas sebesar 0,745; menunjukkan bahwa berbagi informasi mempunyai pengaruh positif terhadap keselarasan kualitas, artinya semakin tinggi tingkat berbagi informasi maka keselarasan kualitas juga akan semakin meningkat. Hasil perhitungan statistik menunjukkan tingkat signifikansi sebesar $0,000(<0,05)$ di mana angka tersebut menunjukkan nilai yang signifikan.

Nilai signifikansi dalam uji $\mathrm{F}$ adalah sebesar $0.000(<0,05)$ artinya terdapat pengaruh variabel $\mathrm{X}$ (berbagi informasi) terhadap variabel $\mathrm{Z}$ (keselarasan kualitas) dengan koefisien 
determinasi sebesar $42 \%$ sedangkan 58\% sisanya dijelaskan oleh variabel lain di luar penelitian. Analisis regresi tahap II menjelaskan pengaruh variabel berbagi informasi (X) dan keselarasan kualitas (Z) terhadap kualitas produk (Y).

Tabel 3. Ringkasan Hasil Analisis Regresi Tahap II

\begin{tabular}{llll}
\hline \multicolumn{1}{c}{ Variabel Independen } & B & t & Sig. \\
\hline Konstanta & 3,781 & 1,653 & 0,103 \\
Berbagi Informasi & 0,273 & 2,096 & $0,040^{*}$ \\
Keselarasan Kualitas & 0,551 & 4,855 & $0,000^{* *}$ \\
\hline
\end{tabular}

Variabel dependen: Kualitas Produk

Adjusted R Square $=0,520$

$\frac{\mathrm{F}=35,640, \text { Sig. } \mathrm{F}=0,000 * *}{* * \operatorname{Sig}<1 \%, * \mathrm{Sig}<5 \%}$

Berdasarkan tabel 3 dapat diketahui persamaan regresi yang diperoleh adalah $\mathrm{Y}=$ $3.781+0,273 X+0,551 \mathrm{Z}$. Hasil tersebut menunjukkan koefisien berbagi informasi sebesar 0273; menunjukkan bahwa berbagi informasi mempunyai pengaruh positif terhadap kualitas produk, artinya semakin tinggi tingkat berbagi informasi maka kualitas produk juga akan semakin meningkat. Hasil perhitungan statistik menunjukkan tingkat signifikansi 0,040 (< $0,05)$ dimana angka tersebut menunjukkan nilai yang signifikan. Hasil koefisien hubungan keselarasan kualitas sebesar 0,551; menunjukkan bahwa keselarasan kualitas mempunyai pengaruh positif terhadap kualitas produk, artinya semakin tinggi tingkat keselarasan kualitas maka kualitas produk juga akan semakin meningkat. Hasil perhitungan statistik menunjukkan tingkat signifikansi $0,000(<0,05)$ dimana angka tersebut menunjukkan nilai yang signifikan.

Berdasarkan analisis regresi maka dapat ditelusuri analisis jalur sebagai berikut:

0,273

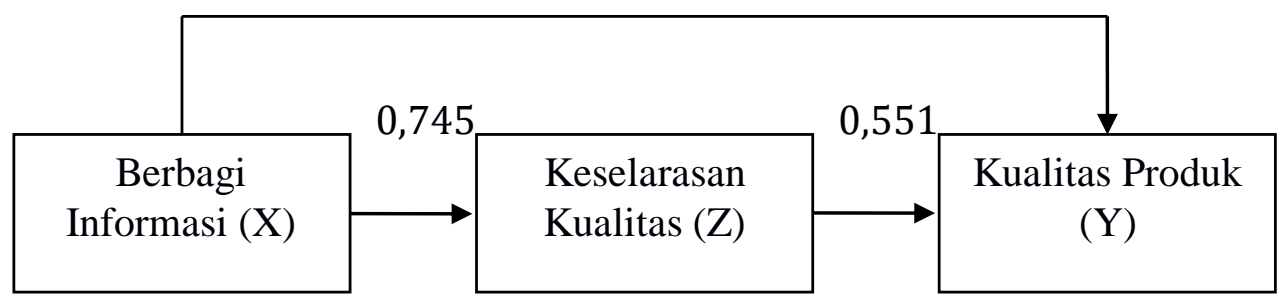

0,683

Gambar 2. Diagram Analisis Jalur

\begin{tabular}{ll} 
Pengaruh langsung $(\mathrm{X} \rightarrow \mathrm{Y})$ & $=0,273$ \\
Pengaruh tidak langsung $(\mathrm{BI} \rightarrow \mathrm{KK} \rightarrow \mathrm{KP})=0,745 \times 0,551$ & $=0,410$ \\
\hline Pengaruh total & $=0,683$
\end{tabular}

Untuk mengetahui pengaruh mediasi signifikan atau tidak maka dilakukan uji mediasi dengan sobel test. Pada penelitian ini nilai t tabel untuk uji validitas responden sebanyak 65 
orang adalah 1,998; diperoleh $\mathrm{z}$ hitung $>\mathrm{t}$ tabel dengan tingkat signifikansi 5\% (3,934 > 1,998). kesimpulannya pengaruh mediasi adalah signifikan.

\section{Pengaruh Berbagi Informasi terhadap Kualitas Produk pada kedai kopi di Sleman, Yogyakarta}

Berdasarkan analisis kuantitatif diketahui pengaruh berbagi informasi (X) terhadap kualitas produk (Y) sebesar 0,273 dengan tingkat signifikansi 0,040 maka terdapat pengaruh positif dan signifikan berbagi informasi terhadap kualitas produk. Apabila tingkat berbagi informasi meningkat maka kualitas produk juga akan meningkat dan berlaku sebaliknya. Dengan demikian hipotesis pertama yang menyatakan "berbagi informasi berpengaruh positif dan signifikan terhadap kualitas produk", diterima.

Hasil penelitian ini sesuai dengan teori Lotfi et al (2013b) yang menunjukkan bahwa meningkatkan berbagi informasi memiliki berbagai manfaat, dan meningkatnya kualitas produk adalah salah satunya. Dengan adanya berbagi informasi dalam integrasi rantai pasokan, maka berpengaruh juga terhadap kualitas produknya. Dalam artian karena berbagi informasi mampu menjaga rantai pasokan dan tentunya berpengaruh pada menjaga dan meningkatkan kualitas produknya pula. Jadi di sini dapat disimpulkan pentingnya berbagi informasi dalam menjaga kualitas produk.

\section{Pengaruh Berbagi Informasi terhadap Keselarasan Kualitas}

Berdasarkan analisis kuantitatif diketahui pengaruh berbagi informasi (X) terhadap hubungan keselarasan kualitas $(\mathrm{Z})$ sebesar 0,745 dengan tingkat signifikansi 0,000 maka terdapat pengaruh positif dan signifikan berbagi informasi terhadap keselarasan kualitas. Apabila tingkat berbagi informasi meningkat maka keselarasan kualitas juga akan meningkat dan berlaku sebaliknya. Dengan demikian hipotesis kedua yang menyatakan "berbagi informasi berpengaruh positif dan signifikan terhadap keselarasan kualitas", diterima.

Hasil penelitian ini menjelaskan bahwa dengan meningkatnya berbagi informasi, maka meningkatkan juga keselarasan kualitas. Bertukar informasi secara rutin dan berkala, bertukar informasi sesuai standar spesifikasi, perencanaan kebutuhan pasokan bahan baku, dan melibatkan pemasok dalam pengembangan produk mampu meningkatkan keselarasan kualitas. Keselarasan kualitas yang dimaksud di sini adalah penyelarasan kualitas bahan baku sesuai dengan standar kedai kopi seperti ukuran, konsistensi warna, aroma, minimalisasi kecacatan, dan kekeringan bahan baku biji kopi.

\section{Pengaruh Keselarasan Kualitas terhadap Kualitas Produk}

Berdasarkan analisis kuantitatif diketahui pengaruh hubungan keselarasan kualitas (Z) terhadap kualitas produk (Y) sebesar 0,551 dengan tingkat signifikansi 0,000 maka terdapat pengaruh positif dan signifikan keselarasan kualitas terhadap kualitas produk. Apabila tingkat keselarasan kualitas meningkat maka kualitas produk juga akan meningkat dan berlaku sebaliknya. Dengan demikian hipotesis ketiga yang menyatakan "keselarasan kualitas berpengaruh positif dan signifikan terhadap kualitas produk”, diterima. 
Hasil penelitian ini sesuai dengan penelitian Lotfi et al (2013c) menunjukkan bahwa keselarasan kualitas berpengaruh positif dan signifikan terhadap kualitas produk. Jadi kesimpulannya hipotesis terbukti. Implikasi hasil penelitian ini dari Lotfi et al (2013c) mengungkapkan bahwa integrasi rantai pasokan dalam menjaga kualitas produk melalui proses keselarasan kualitas terlebih dahulu, dan keselarasan kualitas ini ternyata merupakan hal yang penting.

\section{Pengaruh Berbagi Informasi terhadap Kualitas Produk melalui Keselarasan Kualitas.}

Berdasarkan analisis kuantitatif diketahui pengaruh total berbagi informasi (X) terhadap kualitas produk (Y) yang dimediasi oleh keselarasan kualitas (Z) sebesar 0,683 dan menghasilkan $\mathrm{z}$ hitung $>\mathrm{t}$ tabel pada taraf signifikansi $5 \%(3,906>1,998)$, maka terdapat pengaruh mediasi positif dan signifikan. Artinya keselarasan kualitas mampu menjadi mediasi dalam hubungan berbagi informasi dengan kualitas produk. Dengan demikian hipotesis keempat yang menyatakan "keselarasan kualitas mampu memediasi pengaruh hubungan berbagi informasi terhadap kualitas produk", diterima.

Hasil penelitian ini sesuai dengan teori dan penelitian dari Lotfi et al (2013a) dan Lotfi et al (2013c) di mana hasil penelitiannya menunjukkan bahwa berbagi informasi meningkatkan integrasi rantai pasokan, dan integrasi rantai pasokan akan berpengaruh terhadap kualitas produk melalui keselarasan kualitas. Berdasarkan kajian, semakin lama usaha, maka tingkat berbagi informasi dan kualitas produk juga akan semakin besar. Dengan adanya berbagi informasi inilah membuat hubungan jangka panjang juga antara pihak kedai dan pemasok, yang mana nantinya akan meningkatkan tingkat kualitas produknya. Peran mediasi keselarasan kualitas di sini digunakan untuk menjaga kualitas bahan baku dari pemasok agar selalu memenuhi standar yang sudah ditetapkan oleh pihak kedai kopi.

\section{Kesimpulan}

Berdasarkan hasil penelitian seperti yang diuraikan pada bab sebelumnya, maka dapat ditarik beberapa kesimpulan sebagai berikut: (1) Ada pengaruh secara positif dan signifikan berbagi informasi terhadap kualitas produk pada kedai kopi di Sleman, Yogyakarta. (2) Ada pengaruh secara positif dan signifikan berbagi informasi terhadap keselarasan kualitas pada kedai kopi di Sleman, Yogyakarta. (3) Ada pengaruh secara positif dan signifikan keselarasan kualitas terhadap kualitas produk pada kedai kopi di Sleman, Yogyakarta. (4) Keselarasan kualitas berperan sebagai mediasi dalam pengaruh berbagi informasi terhadap kualitas produk pada kedai kopi di Sleman, Yogyakarta. Berdasarkan kesimpulan tersebut, selanjutnya dapat diusulkan saran yang diharapkan bermanfaat bagi pihak kedai kopi di Sleman sebagai berikut. Pihak kedai kopi perlu meningkatkan kegiatan saling berbagi informasi dengan pemasok dalam hal penyediaan bahan baku untuk menjaga kualitas produk yang terjamin dan memberikan kualitas sesuai dengan standarisasi tiap-tiap kedai kopi. Dalam hal ini diperlukan juga pemasok menjaga hal tersebut, artinya pemasok juga harus menjaga ketersediaan bahan baku, dan hal ini bisa dilakukan salah satunya dengan berbagi informasi, dengan adanya rencana yang tepat di antara kedua pihak maka akan tercipta jaminan bahan baku dan kualitas produk. Dalam hal menjaga kualitas produk, maka tiap 
kedai kopi juga harus memiliki standarisasi dalam pemilih bahan baku kopi mereka, dengan begitu kualitas yang dihasilkan selalu terjamin.

\section{Implikasi, Keterbatasan dan Saran}

Penelitian sebelumnya menunjukkan manfaat bahwa berbagi informasi dapat memberi manfaat mengenai integrasi rantai pasokan, dan nantinya rantai pasokan ini cukup berpengaruh terhadap kualitas produk yang dihasilkan. Maka dari itu hubungan antara pemasok dan pengelola dalam menjamin keselarasan kualitas perlu dijaga. Dalam hal ini tidak hanya pihak pengelola yang ambil andil, namun pihak pemasok juga harus memastikan bahwa persediaan yang disediakan untuk pengelola juga terpenuhi. Semua ini tidaklah luput dari peran berbagi informasi dalam menjaganya.

Penelitian ini tidak terlepas dari beberapa keterbatasan atau hambatan, pertama, responden penelitian ini terbatas pada wilayah Sleman, Yogyakarta saja, maka tidak terlalu luas cakupannya. Hal ini berdampak pada kecilnya cakupan hasil kuisioner. Kedua, dimensi yang diambil dari integrasi rantai pasokan hanya dimensi berbagi informasi saja, maka dari itu lebih baik apabila menambahkan dimensi lain pada penelitian selanjutnya untuk mencoba membuktikan variabel lain yang berpengaruh pada kualitas produk.

\section{Daftar Pustaka}

Anatan, L., \& Ellitan (2008). Supply Chain Management: Theory and Application. Alfabeta: Bandung

Boyd, W, \& Larreche (2000). Manajemen Pemasaran: Suatu Pendekatan Strategis dengan Orientasi Global (edisi kedua). Jakarta: Erlangga

Clark K, B., \& Fujimoto T. (1991). Product development performance: Strategi, organization, and management in the world auto industry. Harvard Business Press

Flynn B, B., Huo B \& Zhao X. (2010). The Impact of Supply Chain Integration on Performance: A Contingency and Configuration Approach. Journal of Operations Management. 28, 58-71

Flynn B, B., Sakakibara, S., Schroede, R., Bates, K \& Flynn, J. (1990). Empirical Research Methods in Operations Management, Journal of Operational Management, 9(2), 250-284

Fujimoto T. (1999). The evolution of a manufacturing system at Toyota, Productivity Press

Garson, D. (2003). Path Analysis, North Carolina State University

Garvin, D, A. (1998). Managing Quality, The New York Press.

Ghozali, I (2018). Aplikasi Analisis Multivariate dengan Program SPSS. Semarang: BP Universitas Diponegoro.

Gunasekaran, A., \& Ngai, E. W. T. (2004). Information Systems in Supply Chain Integration and Management, European Journal of Operational Research. 159, 269-295.

Heizer \& Render (2005). Operation Management, New Jersey: Prentice Hall

Juran J. M. (2007). Juran on leadership for quality, Free Press

Kotler, P. (2005). Manajemen Pemasaran, Edisi Milenium, Jilid Kesatu dan Kedua, Jakarta: PT. Prenhalindo

Kotler, P., \& Armstrong (2007). Prinsip-prinsip Marketing (edisi 7). Jakarta: Salemba Empat

Kusnendi (2008). Model-Model Persamaan Struktural. Bandung: Alfabeta 
Lee, H.L., \& Whang S. (2004). E-business and Supply Chain Integration, Vol. 62. Springer, New York, NY

Li, S., Bhanu R-N, T.S. Ragu N, S. \& Subba, R (2002). The impact of Supply Chain Management Practices on Competitive. The Journal International of Management Science

Lotfi, Z., Sahran S., \& Mukhtar M. (2013a). A Product Quality - Supply Chain Integration Framework. Journal of Applied Sciences. 13: 36-48

Management. 11:298-304

(2013b). Information Sharing in Supply Chain

(2013c). The Relationships between Supply Chain Integration and Product Quality. 11: 471-478

Lupiyoadi, R (2001). Manajemen Pemasaran Jasa, Teori dan Praktek. Edisi Pertama. Jakarta: Salemba Empat

Meirovich, G (2006). Quality of Design and Quality of Conformance: Contingency and Synergistic Approches. University of Massachusetts Boston

Miguel. P, L., \& Brito. L. A. (2011). Supply Chain Management Measurement and Its Influence on Operational Performance. Journal of Operations Management. 4, 5670

Montgomery, D.C. (2007). Introduction to statistical quality control. Wiley-India

Mullins, O., Larrenche, \& Boyd (2005). Marketing Management: A Strategic, Decision Making Approach, $6^{\text {th }}$ Edition. New York, McGraw-Hill

Narasimhan, R., \& Kim, S, W. (2002). Effect of Supply Chain Integration on The Relationship between Diversitification and Performance: Evidence from Japanese and Korean Firms. Journal of Operations Management. 20, 303-323

Pujawan, I, Nyoman (2005). Supply Chain Management, Edisi Pertama. Surabaya: Guna Widya

Reeves, C. \& Bednar, D. (1994). Defining Quality: Alternatives and Implications. The Academy of Management Review. (19)3, 419-445.

Russell, Roberta S, \& Taylor, Bernard W. (2011). Operations Management: Creating Value Along The Supply Chain $7^{\text {th }}$ ed. USA, Wiley

Saladin, D (2002). Manajemen Pemasaran: Analisis, Perencanaan, Pelaksanaan, dan Pengendalian. Bandung: Penerbit Linda Karya

Sugiyono (2010). Metode Penelitian Bisnis. Bandung: Alfabeta.

Sekaran, U. (2006). Metodologi Penelitian untuk Bisnis, Edisi 4, Buku 1. Jakarta: Salemba Empat.

Whipple., Lynch, \& Nyaga (2010). Examining Supply Chain Relationships: Do Buyer and Supplier Perspectives on Collaborative Relationships Differ?. Journal of Operations Management 28(2)

Yaqoub, M. \& Amak (2012). Pengaruh Mediasi Kepercayaan pada Hubungan antara Kolaborasi pada Hubungan antara Kolaborasi Supply Chain dan Kinerja Operasi. Jurnal Manajemen dan Kewirausahaan Vol. 14 No. 2 